\title{
Preliminary phases of the HIDRALERTA system: Assessment of the flood levels at S. João da Caparica beach, Portugal
}

\author{
Paulo Duarte Raposeiroł, Conceição Juana Fortesł, Rui Capitãoł, Maria Teresa Reisł, José Carlos \\ Ferreira†, Maria Teresa Sá Pereira $\infty$ and José Guerreiro $\infty$ \\ †Universidade Nova de Lisboa - \\ FCT/DCEA \& CENSE - Centre for \\ Environmental and Sustainability Research, \\ Campus de Caparica, 2829-516, Portugal \\ praposeiro@fct.unl.pt \\ jcrf@fct.unl.pt \\ $\ddagger$ National Laboratory for Civil \\ Engineering (LNEC) - Harbours and \\ Maritime Structures Division, Avenida \\ do Brasil 101, 1700- 066 Lisboa, Portugal \\ jfortes@lnec.pt \\ rcapitao@lnec.pt \\ treis@lnec.pt \\ $\infty$ Lisbon Port Authority (APL) \\ Rua da Junqueira, 94, 1349-026 \\ Lisboa, Portugal \\ tpereira@portodelisboa.pt \\ jguerreiro@portodelisboa.pt
}

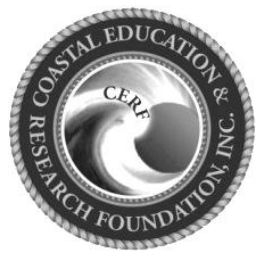

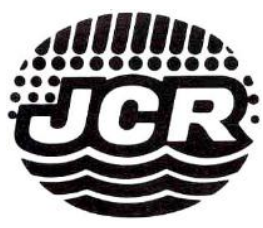

www.JCRonline.org

\section{ABSTRACT}

Raposeiro, P.D., Fortes, C.J.E.M., Capitão, R., Reis, M.T., Ferreira, J.C., Pereira, M.T.S., Guerreiro, J., 2013 Preliminary phases of the HIDRALERTA system: Assessment of the flood levels at S. João da Caparica beach, Portugal. In: Conley, D.C., Masselink, G., Russell, P.E. and O'Hare, T.J. (eds.), Proceedings $12^{\text {th }}$ International Coastal Symposium (Plymouth, England), Journal of Coastal Research, Special Issue No. 65, pp. 808-813, ISSN 0749-0208.

\begin{abstract}
The length of the Portuguese coast, the severity of the sea conditions and the concentration of population and economic activities on its coastal zone justify the importance of studying wave-induced risks and, in particular, flooding due to wave action. Indeed, emergency situations caused by adverse sea conditions are frequent and put in danger the safety of people and goods, with negative impacts for society, economy and natural heritage. So, assessing the risk of flooding of coastal and port areas is essential for the proper planning and management of these areas. In this framework, a methodology for the flood risk assessment in coastal and port areas is under development. The methodology is embedded into the HIDRALERTA system, a novel integrated system for port and coastal management, designed to prevent emergency situations, to support their management and to forecast incidental long-term interventions. The present paper describes the methodology, the HIDRALERTA system and a case study, the São João da Caparica beach, on the Lisbon's area, where the referred methodology was recently applied. Sea wave characterization and flood level calculations are presented for the study.
\end{abstract}

ADDITIONAL INDEX WORDS: Coastal Planning and Management, Geographic Information System, Numerical Models, Flooding, Costa da Caparica.

\section{INTRODUCTION}

The evaluation of the flooding and wave overtopping of maritime structures in coastal zones and ports is very important to enable assessment of the risk related with either the failure of those structures or the flooding of the regions protected by them. This is also an urgent matter to Portugal, due to its quite long coastline, the high concentration of population on that coastline, the economic activities related to the sea, its severe sea-wave climate and, finally, the relevance of port commerce and industry for the national economy.

Emergency situations caused by sea waves hitting the coast are unfortunately quite common, usually endangering the safety of people and goods and having serious consequences for the economy and society (Reis et al., 2012). Recent examples are the flooding at Esmoriz, 17/02/2011, due to overtopping of the seawall, with damages in the infrastructure and homes along the seafront; the frequent overtopping of Estoril seawall, which affects its use and disrupts the nearby railway line; the strong overtopping of the breakwater of Praia da Vitoria port, completely destroyed after the December 2001 storm; the massive breakwater overtopping of the Marina do Lugar de Baixo, Madeira, 2006, damaging this structure quite seriously and leading to the marina inoperability.

DOI: 10.2112/S165-137.1 received 07 December 2012; accepted 06 March 2013.

(c) Coastal Education \& Research Foundation 2013
Therefore, it is deemed of paramount importance to put in operation a warning system that is able to forecast the occurrence of emergency situations and enables the adoption, by the national or local authorities, of measures to prevent live losses and to reduce economic and environmental damages. This system may also act as a long-term management tool since it can be used to simulate the phenomenon response to long series of historical data thus enabling the definition of risk maps, as well as the study of the response to future scenarios related to climate change, such as the increase in the mean sea level and/or in the storm severity, which will increase the probability of coastal flooding.

It is worth mentioning that such a system may contribute to comply with the directive 2007/60/CE from the (EU, 2007) in what concerns the elaboration by the member states of flood risk maps before 22 Dec 2013 (Chap.III-Art.6-8) and of risk management plans, including forecast, alert and warning systems, before 22-12-2015 (Chap.III-Art.7-3).

As a consequence, in the last decade, studies are being carried out in Portugal for the assessment of risks associated with the occurrence of overtopping in coastal and harbour areas using Geographic Information Systems (GIS) capabilities (e.g., Raposeiro et al., 2011) and for forecasting and warning those occurrences (e.g., Santos et al., 2010). Some are still based on runup calculations only, using empirical formulations (e.g., Almeida et al., 2012); others evaluate mean overtopping discharges, based on empirical formulae and/or the NN_OVERTOPPING2 tool 
(e.g., Raposeiro et al., 2011). These studies are mainly carried out under research contracts, both national and European (e.g., under the FP7 MICORE project - www.micore.eu), and include assessment of existing defenses to ensure that safety standards are maintained. The methodologies and tools are being developed and tested for several Portuguese harbors and locations along the coast but no prototypes exist still.

Therefore, the new Forecasting and Warning System for Floods in Coasts and Ports, entitled HIDRALERTA, is being developed under a Portuguese research contract, being unique in Portugal and stemming from the basic idea of using the sea-wave forecasts to calculate their effects in terms of overtopping and flooding. Comparing these values with pre-determined thresholds will allow: i) real-time assessment of emergency situations, issuing alert messages to the authorities, whenever the safety of people, property or activities in those areas is at risk; ii) construct risk maps considering either long-term series of forecast sea-wave characteristics or pre-defined scenarios associated with climate change or extreme events. The HIDRALERTA system is at its first stages of development and it is planned to be operative by 2014. Universidade Nova de Lisboa and LNEC are in charge of its development and maintenance.

The paper presents the work done so far on the establishment of the HIDRALERTA system. It starts with a general description of HIDRALERTA methodology. Then, the first steps of that methodology, namely the determination of the wave regime and the flood levels, are presented for the study case of S. João da Caparica beach.

\section{HIDRALERTA METHODOLOGY}

The main goal of the project is to develop a new forecast, alert and long-term risk analysis system, the HIDRALERTA system, to deal with overtopping and flood events in coastal and port areas. Its ultimate purpose is to create user-friendly tools that will convey to the authorities important information on flood risks at their regions (risk maps), thus enabling management decisions or mitigation measures to be made in a sustainable and integrated way. In emergency situations, the system will alert the authorities in such a way as to minimize the economic and environmental losses associated to floods caused by wave activity.

Using the forecast sea wave conditions at coastal and port areas, the system determines the effects of the waves in terms of overtopping and flooding, compares those results with prespecified thresholds and builds corresponding alert maps, and, if necessary, issues alert messages to the authorities. HIDRALERTA will also construct risk maps, based upon vulnerability maps and for that will evaluate overtopping and flood levels, considering data coming from long-time series of sea wave characteristics or from predefined scenarios associated, for instance, with climate change or extreme events.

HIDRALERTA will be presented as a Web interface with the following modules:

- A database module containing the relevant information of the study areas;

- A module for the estimation of overtopping and flood on coastal areas and ports, which includes the evaluation of a) wave conditions at the study areas from hindcast offshore values; b) sea wave effects in terms of run-up/overtopping of coastal and port structures; c) sea wave effects in terms of flooding of coastal areas;

- An alert system;

- Risk maps.

The main ideas behind the system are:
- use of GIS to coordinate all those functionalities. GIS is adopted because of its great capability to organize and interpret large amounts of data and to extract information, quickly showing trends and patterns, essential features for any decision maker;

- use of a GIS integrated system for wave propagation in coastal and ports. The coupling of the hindcast model WWIII (Tolman, 1999) with the wave propagation models SWAN (Booij et al. 1999) and DREAMS (Fortes, 2001) will turn the new system into a forecast one;

- use of the nonlinear wave propagation BOU model (Pinheiro et al. 2009) for a better characterization in port areas. For that, modifications of BOU model as to couple it with other models, as well as the implementation of a new numerical method to solve nonlinear instabilities, are foreseen.

- use of a new methodology for run-up/overtopping calculations based on combining the several procedures available in the literature to overcome their drawbacks;

- automated construction of overtopping and flood alert maps based on the forecast of sea wave conditions. These will be new tools that will allow a clear and easy way to show the authorities what is going on in the different areas of the study region in terms of overtopping and flooding;

- issue alerts when flooding exceeds predefined thresholds;

- produce flood risk maps for the study areas.

Two sites were chosen to test the proposed system: S. João da Caparica Beach, on the mainland Portugal, where flooding and overtopping risks are associated to the safety of people/houses (restaurants), roads, and the Praia da Vitória harbour, on the Terceira Island (Azores), where the risks are associated mainly to port infrastructures and activities.

\section{CASE STUDY}

\section{S. João da Caparica beach}

The S. João da Caparica beach is located on the south of the mouth of the Tagus River, in the Almada municipality and just opposite to the city of Lisbon (Figure 1). It is a large beach and a main bathing area of great importance to both the cities of Lisbon and Almada, also constituting a recreational main spot for local residents and tourists throughout the year. The S. João da Caparica beach has a length of approximately $1.3 \mathrm{~km}$, being confined in between two groins (the northern groin, $350 \mathrm{~m}$ long, and the south groin, $150 \mathrm{~m}$ long). It is of sandy sedimentary origin and is characterized by a small, yet very fragile, dune system, including a number of wooden constructions (bars and restaurants) on the frontal dune.

In recent years, there has been a number of main interventions (sand fillings and beach reconstruction spurs), performed locally to mitigate the effects of passed storms that occurred at the site. The loss of sediment on the beach was a main "footprint" of these storms, visible over the years, which greatly contributed to increase the fragility of the (already week) dune system and to also endanger the stability of existing constructions at the site.

\section{Selection of the case study}

The selection of the case study was thus defined according to the analysis of the history of destructive storm events at the site. In February 2010 the last event of great dimensions occurred at S. 


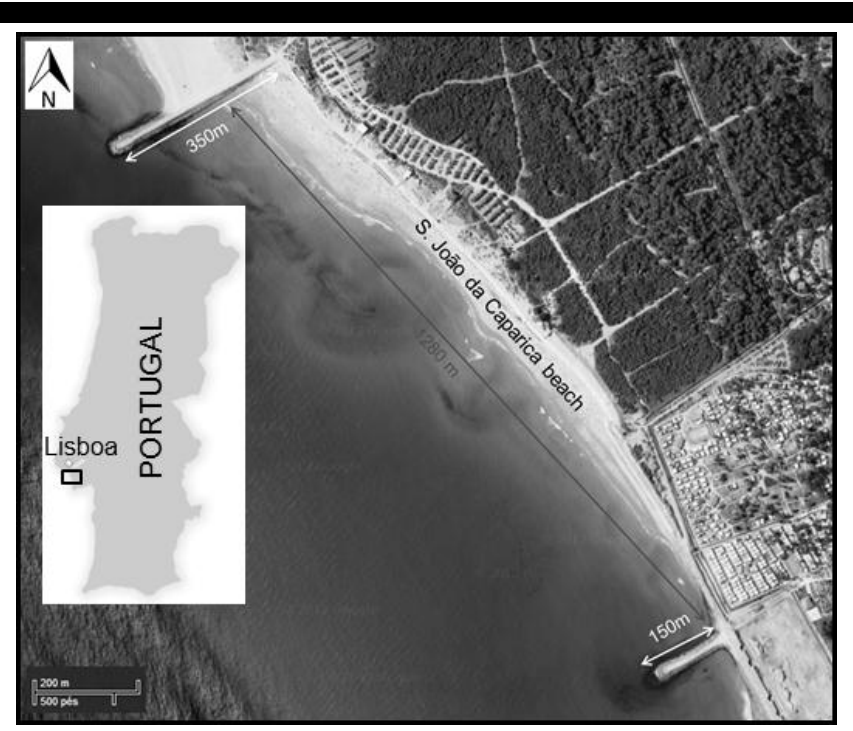

Figure 1. Study area location - S. João da Caparica beach.

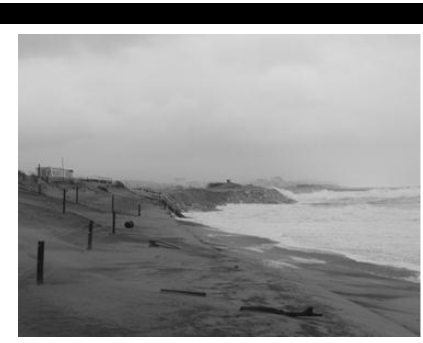

a) Beach profile

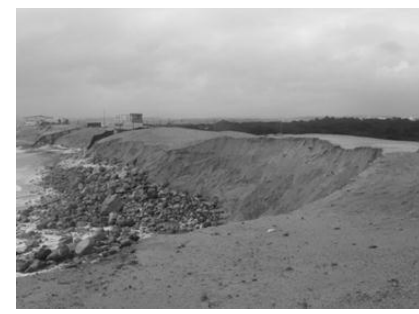

c) Dune erosion

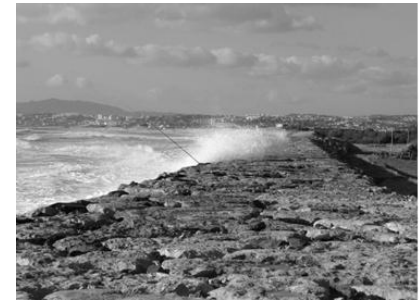

e) Run-up of the structure

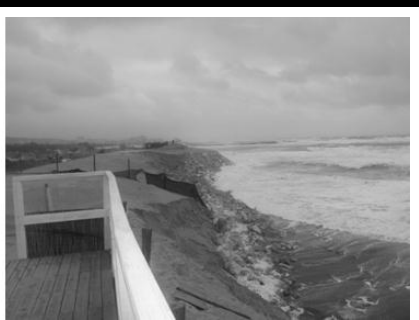

b) Base of dune erosion

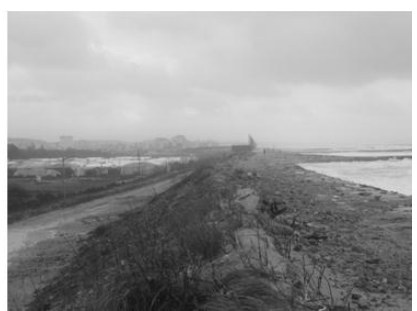

d) Water channel on beach

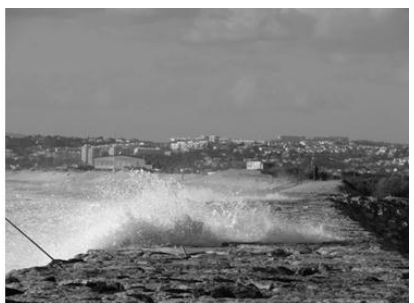

f) Structure overtopping

Figure 2. Effects of the 27.02.2010 storm at S. João da Caparica beach.

João da Caparica beach. Figure 2 shows some visual aspects of the consequences of this destructive episode.

In order to characterize this area in terms of the risk related with either the failure of the structures belonging to this beach or the potential flooding, a general wave characterization had to be established beforehand. Therefore, wave data coming from a wave-buoy, located at the entrance of Lisbon Estuary, provided by the Lisbon Port Authority (APL), were used in this work.

\section{Characteristics of the local wave regime at the Port of Lisbon wave-buoy}

For the characterization of the local wave regime at the coastal area of the study, wave parameters measured with the TRIAXYS wave-buoy from the Port of Lisbon were used. The buoy is located at the bathymetric of $-30 \mathrm{~m}(\mathrm{CD})$, at the south entrance of the Lisbon Harbor navigational channel, at position with coordinates $38^{\circ} 37^{\prime} 25^{\prime}$ ' $\mathrm{N}, 09^{\circ} 23^{\prime} 09^{\prime}$ ' W. In normal conditions, the wave parameters, such as the significant wave height (HS), the mean wave period (TZ), the peak wave period (TP) and the mean wave direction (DIR) are produced every 1 hour, based on 20-minduration wave-buoy acquisitions.

Wave data used in this paper refer to a period from 30-12-2005 to 16-11-2012. It should be noted however that a significant number of gaps (some of them quite extended) are apparent in this approximately 7-year duration. Also, a number of outliers were identified on the original records of the wave parameters, which were promptly removed for the present analysis.

As such, based on the available (and valid) data, Figures 3 to 5 show a small excerpt of the time-series of parameters HS, TZ and DIR, i.e., for period from Jun 2011 to Jun 2012 only, since legibility of figures showing the whole series is compromised. Note however that the period shown in Figures 3 to 5 should not be viewed as representative of the whole 7-year-period data series. Table 1 shows some main statistics of the same parameters for the whole data period (from 30-12-2005 to 16-11-2012).

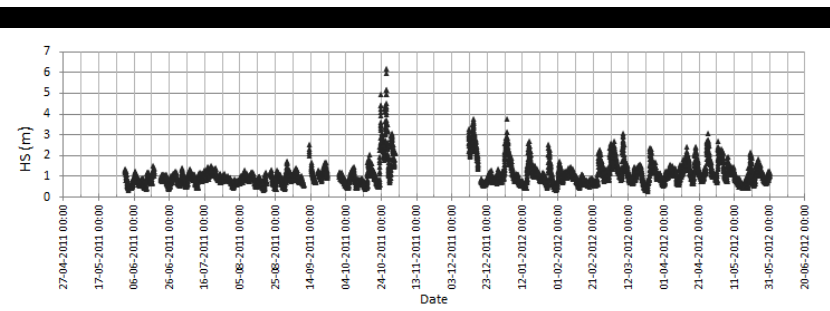

Figure 3. Wave height (HS) at the Lisbon wave-buoy for the period Jun 2011-Jun 2012

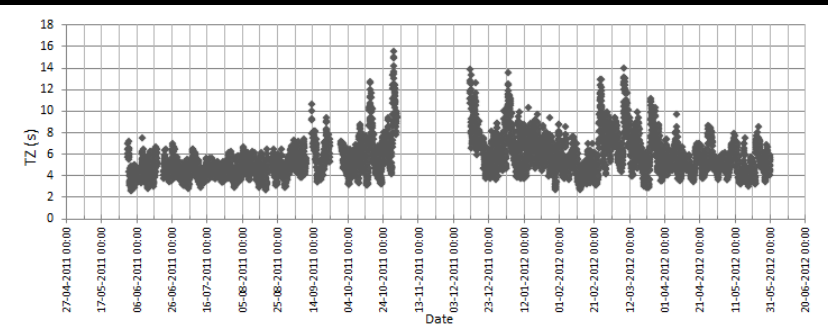

Figure 4. Wave period (TZ) at the Lisbon wave-buoy for the period Jun 2011-Jun 2012. 


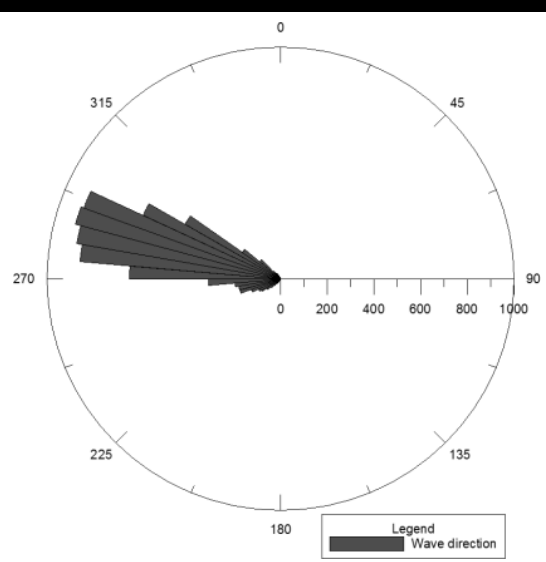

Figure 5. Wave direction (DIR) at the Lisbon wave-buoy for the period Jun 2011-Jun 2012.

Table 1 - Minimum, mean, maximum and most frequent range for the parameters HS, TZ and DIR at the Lisbon wave-buoy from 30-12-2005 to 16-11-2012.

\begin{tabular}{lcccc}
\hline Parameters & Minimum & Mean & Maximum & $\begin{array}{c}\text { Most } \\
\text { Frequent } \\
\text { Range }\end{array}$ \\
\hline HS (m) & 0.27 & 1.22 & 6.19 & $0.5-2.0$ \\
\hline TZ (s) & 2.3 & 5.7 & 15.5 & $5-12$ \\
\hline TP $(\mathbf{s})$ & 1.9 & 10.6 & 28.6 & $7-15$ \\
\hline DIR $\left(^{(}\right)$ & 0 & 280 & 360 & $260-310$ \\
\hline
\end{tabular}

\section{Analysis of the run-up at S. João da Caparica beach}

\section{Methodology}

Currently, the simplest way of estimating the beach run-up is essentially by using empirical formulations based on field measurements and on simplified bidimensional models, for straight and impermeable embankments (USACE, 2003). In this work, several run-up formulas have been used and are presented in Table 2, following the work of Sancho et al. (2011).

Table 2 - Run-up formulations (adapted from Sancho et al., 2011)

\begin{tabular}{|c|c|}
\hline $\begin{array}{l}\text { Author } \\
\text { s }\end{array}$ & Formula \\
\hline $\begin{array}{l}\text { Hunt } \\
\text { (1959), } \\
\text { Battjes } \\
(1971)\end{array}$ & $R_{2 \%}=m\left(H S L_{0 p}\right)^{0.5}$ \\
\hline $\begin{array}{l}\text { Holman } \\
(\mathbf{1 9 8 6 )}\end{array}$ & $R_{2 \%}=H S\left(0.38 \xi_{0 p}+0.2\right)$ \\
\hline $\begin{array}{l}\text { Nielsen \& } \\
\text { Hanslow } \\
\text { (1991) }\end{array}$ & $\begin{aligned} \mathrm{R}_{2 \%} & =\mathrm{L}_{\mathrm{Ru}}(-\ln (0.02))^{0.5} \\
L_{R u} & = \begin{cases}0.6 m\left(H_{r m s} L_{0 s}\right)^{0.5} \text { if } & m \geq 0.10 \\
0.05\left(H_{r m s} L_{0 .}\right)^{0.5} \text { if } & m<0.10\end{cases} \end{aligned}$ \\
\hline $\begin{array}{l}\text { Raubenh } \\
\text { eimeir \& } \\
\text { Guza } \\
(\mathbf{1 9 9 6 )} \\
\end{array}$ & $R_{2 \%}=\frac{1}{\pi} H S \xi_{0 p}^{2}$ \\
\hline $\begin{array}{l}\text { Masselin } \\
\text { k \& } \\
\text { Hughes }\end{array}$ & $\mathrm{R}_{2 \%}=0.36 \mathrm{~m}(\mathrm{gHS})^{0.5} \mathrm{TP}$ \\
\hline
\end{tabular}

\section{(2003)}

Stockdon $R_{2 \%}=1.1\left\{0.35 m\left(H S L_{0 p}\right)^{0.5}+0.5\left[H S L_{0 p}\left(0.563 m^{2}+0.004\right)\right]^{0.5}\right\}$

et al.

(2006) $\quad \mathrm{R}_{2 \%}=0.043 \sqrt{\mathrm{HSL}_{0 \mathrm{p}}}$ for $\xi_{0 p}<0.3$

In Table $2 \mathrm{R}_{2} \%$ is the run-up value exceeded by $2 \%$ of the individual run-ups; $m$ is the mean beach face slope; HS is the significant wave height at the wave-buoy; $\mathrm{H}_{\mathrm{rms}}$ is the root mean square wave height; $g$ is the gravitational acceleration; $\xi_{0 \mathrm{p}}$ is the breaker parameter (or Iribarren number) given by $\mathrm{m} /\left(\mathrm{HS} / \mathrm{L}_{0}\right)^{0.5}$, in which $\mathrm{L}_{0}$ is the deep-water wavelength, according to linear wave theory, corresponding to $\mathrm{TP}\left(\mathrm{L}_{0 \mathrm{p}}\right)$ or $\mathrm{TS}\left(\mathrm{L}_{0 \mathrm{z}}\right)$, with $\mathrm{TS}=\mathrm{TP} / 1.05$, depending on the run-up formulation (Iribarren \& Nogales, 1949; Battjes, 1974).

The wave regime (HS, TP and DIR) was measured at the Lisbon wave-buoy and the characteristics of the dissipative beach of S. João da Caparica, with a mean gradient of 1:16 $(\mathrm{m}=0.0625)$ were considered, see Figure 6 . The beach profiles were obtained from a 29.10.2012 survey which showed a winter profile transition. It should be noted that during the last 15 years this beach has undergone several changes to its profile (Pinto et al. 2007). The above formulations were applied for the estimation of the $2 \%$ runup values and the associated flood levels.

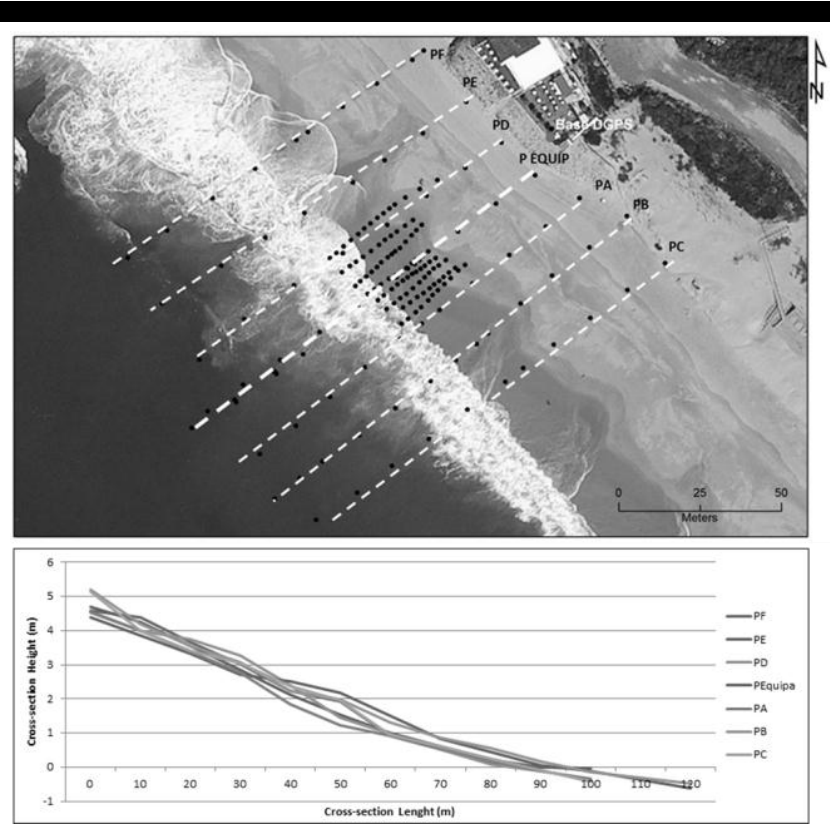

Figure 6. Cross-sections in S. João da Caparica beach

The application of such formulations was performed by using a FORTRAN program (Fortes et al., 2009 \& 2012). Its output values are shown in Table 3 and Figure 7.

\section{Results}

In general, the $\mathrm{R}_{2 \%}$ values obtained with the different formulations are quite similar, except for the Raubenheimer \& Guza (1996) formulation, which led to the lowest values of $R_{2 \%}$, and the formulation of Nielsen \& Hanslow (1991), which led to the highest values. Consequently, the results obtained from these two formulations were discarded for the determination of the flood levels and an average value for the $\mathrm{R}_{2 \%}$ was adopted, using the values from the remaining formulations. In fact, the remaining $\mathrm{R}_{2 \%}$ curves show the same behaviour and the respective mean and maximum values of $\mathrm{R}_{2 \%}$ are of the same order of magnitude. The 
differences in the results obtained from the various formulations are mainly related to the characteristics of the beaches (e.g. mean slope of the beach face, type of beaches - dissipative or reflective) and wave conditions from where the different authors took their data to propose the empirical formulations.

Table 3 - S. João da Caparica beach. Mean and maximum $\mathrm{R}_{2} \%$ for the period from 2006 to 2012.

\begin{tabular}{lcc}
\hline \hline \multirow{2}{*}{ Authors } & \multicolumn{2}{c}{$\mathbf{R}_{\mathbf{2} \%}(\mathbf{m})$} \\
\cline { 2 - 3 } & Mean & Maximum \\
\hline Hunt (1959), Battjes (1971) & 0.90 & 4.79 \\
\hline Holman (1986) & 1.00 & 4.97 \\
\hline Nielsen \&Hanslow (1991) & 1.19 & 6.32 \\
\hline Raubenheimer \& Guza (1996) & 0.21 & 1.46 \\
\hline Masselink \& Hughes (2003) & 0.81 & 4.32 \\
\hline Stockdon et al.(2006) & 0.98 & 5.25 \\
\hline
\end{tabular}

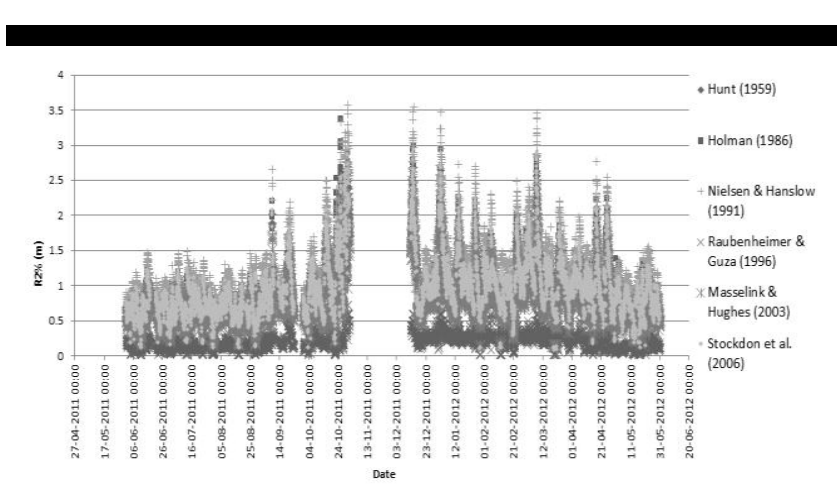

Figure 7. S. João da Caparica beach. Run-up values, $\mathrm{R}_{2 \%}$, obtained for the wave conditions at Lisbon wave-buoy for the period Jun 2011-Jun 2012.

\section{Calculation of the flood levels}

Once the run-up values for a given wave regime are calculated, the flood levels, FL (m CD), can be determined assuming that they result from the sum of the contributions of the astronomical tide, AT (m CD), of the surge level, SL, and of the $2 \%$ run-up, $\mathrm{R}_{2 \%}$ :

$$
\mathrm{FL}=\mathrm{AT}+\mathrm{SL}+\mathrm{R}_{2 \%}
$$

This expression is a simplified way of estimating the FL, since the flood level of a coastal area is a complex phenomenon, due to the multiple factors involved in the process and their interactions (see, for example, Stockdon et al., 2007; Del Rio et al., 2012).

In this work, since it was not possible to obtain in due time measurements of water levels from the tide gauge of Port of Lisbon, for the period from 2006 to 2012, two extreme levels (MLWS and MHWS) for the AT in this period (IH, 2006, 2007, 2008, 2009, 2010, 2011 and 2012) were used instead in order to estimate the corresponding flood levels. These levels have been corrected to account for the increase of $3.57 \mathrm{~mm} /$ year in the MWL in this area (Antunes, 2011): MHWS $=3.74 \mathrm{~m}(\mathrm{CD})$ and MLWS $=0.85 \mathrm{~m}(\mathrm{CD})$. The maximum flood levels will correspond to a MHWS, since wave storms in the Portuguese coast, which give rise to high storm surges, will have a storm duration most frequently above 12 hours (Costa et al., 2001).

The storm surge, SL, is the difference between the measured values of the water level and the ones estimated for the astronomical tide. This elevation is considered to be induced by strong and/or long-lasting winds and/or by abnormal high or low atmospheric pressures. In this work due to the lack of data relative to the years from 2006 to 2012, a constant value of $\mathrm{SL}=0.52 \mathrm{~m}$ was adopted, based on the studies performed by Gama et al. (1997).

The values of $\mathrm{AT}+\mathrm{SL}$ considered are then $0.85 \mathrm{~m}$ (CD) (MLWS) and $4.25 \mathrm{~m}$ (CD) (MHWS+SL).

The results for the flood levels are presented in Table 4 and Figures 8 and 9.

Table 4 - Minimum, average and maximum flood levels (m CD) at S. João da Caparica beach for the period from 2006 to 2012.

\begin{tabular}{lccc}
\hline \hline & \multicolumn{3}{c}{ FL (m CD) } \\
\cline { 2 - 4 } & Minimum & Average & Maximum \\
\hline MLWS & 0.93 & 1.69 & 5.24 \\
\hline MHWS & 4.33 & 5.09 & 8.64 \\
\hline
\end{tabular}

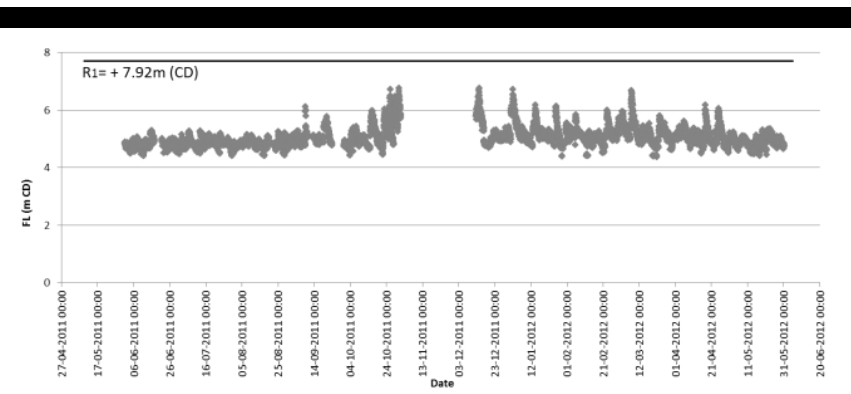

Figure 8. Flood levels (m CD) at S. João da Caparica beach for the period Jun 2011-Jun 2012, for MHWS.

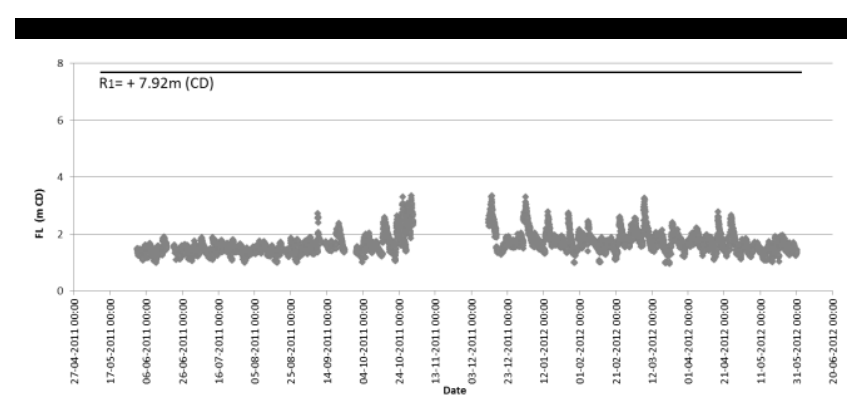

Figure 9. Flood levels (m CD) at S. João da Caparica beach for the period Jun 2011-Jun 2012, for MLWS.

For the highest tide level, the maximum flood level was $8.64 \mathrm{~m}(\mathrm{CD})$ being the average value equal to $5.09 \mathrm{~m}(\mathrm{CD})$. For the minimum tide level, the corresponding maximum flood level was $5.24 \mathrm{~m}(\mathrm{CD})$, being the average value equal to $1.69 \mathrm{~m}(\mathrm{CD})$.

In Figure 8, R1 threshold level is indicated, corresponding to the level of one of the seven existing restaurants on the S. João da Caparica beach. Over the 7 years of recorded data, it was found that for the highest tide value, R1 level was exceeded only $0.2 \%$ of cases. For the low tide level, that value was never exceeded. Notice that the significant flood level values found for 30.10.2010 are in agreement with the characteristics of the serious damages suffered by both the restaurant and the dune, which were due to a severe storm and concurrent flood.

\section{CONCLUSION}

The methodology presented in this paper constitutes a first step to the establishment of the new forecasting and warning system for floods in coasts and ports HIDRALERTA system. 
Based upon the local wave regime, several empirical formulations were used to determine run-up values from 2006 to 2012 in S. João da Caparica beach, Portugal. With those values, it was possible to calculate the flood levels in the beach, considering the contributions of the astronomical tide, MA (m CD) and of the surge level (SM). Two extreme levels for the MA were tested (MLWS and MHWS) in this period.

The results showed that, in general, the different formulations led to similar results in terms of average and maximum run-up values. However, the formulations of Raubenheimer \& Guza (1996) and of Nielsen \& Hanslow (1991) led to the lowest and the highest run-ups, respectively, and were discarded for the determination of an average run-up value used to calculate the flood levels. In terms of flood levels, the results confirmed some flood damage situations verified on this beach during the period of time considered.

The flood level methodology used in this work is meant to be both simple and efficient, enabling one to produce quick estimations of the expected floods. However some features of the presented methodology should be improved, namely by enabling consideration of the time series of measured water levels Improvements of the methodology should also include beach response to wave runup (e.g. by using Xbeach or similar models), as it influences extremely flooding extent. The establishment of a GIS model and the evaluation of the flood risk also constitute future work in this area.

\section{ACKNOWLEDGEMENTS}

The work described in this publication was supported by the "Fundação para a Ciência e a Tecnologia", Portugal, through project HIDRALERTA, ref. PTDC/AAC-AMB/120702/2010. The participation of all members of the HIDRALERTA project is acknowledged.

The help of the Port of Lisbon Authority (APL) and of Dr. Paula Freire on providing local wave and tide data and topographic surveys, respectively, are also acknowledged.

\section{LITERATURE CITED}

Almeida, L.P., Vousdoukas, M.V., Ferreira, O., Rodrigues, B.A., Matias, A., 2012. Thresholds for storm impacts on an exposed sandy coastal area in southern Portugal. Geomorphology, 143-144, pp. 3-12.

Antunes, C., 2011. Variação Actual do NMM em Cascais. VII Conferência Nacional de Cartografia e Geodesia, Porto

Battjes, J.A., 1971. Run-up distributions of waves breaking on slopes Journal of Waterways, Harbors and Coastal Engineering Division, 97, pp. 91-114,

Battjes, J.A., 1974. Surf similarity. Proceedings $14^{\text {th }}$ Coastal Engineering Conference, Copenhagen, Vol.1, 466-480.

Booij, N., Ris, R.C., Holthuijsen, L.H., 1999. A third-generation wave model for coastal regions, Part I, Model description and validation, Journal Geographical Research, C4, 104, 7649-7666.

Costa, M., Silva, R., Vitorino, J., 2001. Contribuição para o estudo do clima de agitação marítima na costa portuguesa. $2^{a} s$ Jornadas Portuguesas de Engenharia Costeira e Portuária, Sines, CD-Rom, 20p.

Del Río, L., Plomaritis, T.A., Benavente, J., Valladares, M., Ribera, P. 2012. Establishing storm thresholds for the Spanish Gulf of Cádiz coast. Geomorphology, 143-144, pp. 13-23.

Fortes, C.J.E.M., 2001. Nonlinear transformations of maritime waves in harbour areas, IST, UTL, PhD. Thesis.

Fortes, C.J.E.M., Reis, M.T., Raposeiro, P.D., 2009 Calculos_NielsenHanslow1991.f. Programa em FORTRAN para a implementação sistemática da fórmula empírica de Nielsen e Hanslow (1991). LNEC/NPE.

Fortes, C.J.E.M., Reis, M.T., Raposeiro, P.D., 2012. Calculos_Multiautores. Programa em FORTRAN para a implementação sistemática das fórmulas empíricas de Hunt (1959)/Battjes (1971), Holman (1986), Nielsen \& Hanslow (1991),
Masselink \& Hughes (2003), Raubenheimer \& Guza (1996) and Stockdon et al. (2006). LNEC/NPE.

Gama, C., Taborda, R., Dias, J.M.A., 1997. Sobrelevação do nível do mar de origem meteorológica "storm surge", em Portugal Continental. Colectânea de ideias sobre a zona costeira de Portugal, Porto: associação Eurocoast - Portugal, pp. 131-149.

Holman, R.A., 1986. Extreme value statistics for wave run-up on a natural beach. Coastal Engineering, 9, pp. 527-544.

Hunt, I.A, 1959. Design of seawalls and breakwaters. Journal of Waterways and Harbours Division, ASCE, 85 (WW3), pp. 123-152

IH, 2006, 2007, 2008, 2009, 2010, 2011 and 2012. Tabelas de Marés, Instituto Hidrográfico- Marinha.

Iribarren, C.R. Nogales C., 1949. Protection des Ports. Section II, Proc. XVII International Navigation Congress, Lisbon, 31-80.Masselink, G., Hughes, M.G., 2003. Introduction to coastal processes and geomorphology. Arnold, London, $354 \mathrm{pp}$.

Nielsen, P., Hanslow, D.J., 1991. Wave run-up distributions on natural beaches. Journal of Coastal Research., 7(4), 1139-1152.

Pinheiro, L., Fortes, C.J., Santos, J.A., Walkley, M., 2009. Implementation of partial reflection boundary conditions in wave propagation model BOUSSIIW. Journal of Coastal Research, SI 56, Lisbon, Portugal.

Pinto, C. A., Taborda, R., Andrade, C., 2007. Evolução recente da linha de costa no troço Cova do Vapor - S. João da Caparica. Proceedings $5^{a}$ Jornadas Portuguesas de Engenharia Costeira e Portuária, Lisboa.

Raposeiro, P.D., Reis, M.T., Neves, D., Fortes, C., Santos, J.A., Vieira, A.S., Ramalheira, J., Simões, A., Azevedo, E.B., Rodrigues, M.C., 2011. Methodology for overtopping risk assessment in port areas. Application to the Port of Praia da Vitória (Azores, Portugal).In:Schüttrumpf, H., Tomasicchio, G. R. (eds.), Proceedings 5th International Short Conference Applied Coastal Research, (Aachen, Germany), pp.536-543, Shaker Verlag.

Raubenheimer, B., Guza, R.T., 1996. Observations and predictions of runup. Journal of Geophysical Research, 101 (C10), pp. 25575-25587

Reis, M.T., Neves, M.G., Didier, E., Ferreira, O., Silva, L.G., Afonso, C., Lopes, M.R., Fortes, C.J., 2012. Maritime structures wave overtopping studies. The Portuguese experience. Proceedings PIANC 2nd Mediterranean Days of Coastal and Port Engineering, 23-25 May, Valencia, Spain, Asociación Técnica de Puertos y Costas (ATPyC), 311-330.

Sancho, F., Oliveira, F.S.B.F., Freire, P., 2011. Níveis máximos do espraiamento no litoral da Ria Formosa. $7^{a} s$ Jornadas Portuguesas de Engenharia Costeira e Portuária, Porto, CD-Rom, 12p.

Santos, J.A., Rodrigues, S., Pinheiro, L., Neves, D.R., Fortes, C.J., Reis, M.T., Simões, A., Azevedo, E.B., 2010. Managing wave-induced risks in port operations. Journal of Coastal Conservation (in press).

Stockdon, H.F., Holman, R.A., Howd, P.A., Sallenger J.r., A.H., 2006 Empirical parameterization of setup, swash and runup. Coastal Engineering, 53, pp. 573-588.

Stockdon, H.F., Sallenger Jr., A. H., Holman, R. A., Howd, P. A., 2007. A simple model for the spatially variable coastal response to hurricanes. Marine Geology, Vol. 238, 1-20.

Tolman, H. L., 1999. User manual and system documentation of WAVEWATCH-III version 1.18, NOAA / NWS / NCEP / OMB technical note $166,110 \mathrm{pp}$.

USACE, 2003. Coastal Engineering Manual. Coastal and Hydraulics Laboratory, U.S. Army Engineer Research and Development Center, Vicksburg, Miss. 